\title{
Ecological problem of modernity as a global problem of humanity
}

\author{
Kseniya Kovalenko $^{1 *}$, and Nataliya Kovalenko ${ }^{1}$ \\ ${ }^{1}$ Altai State University, Barnaul, Russia Federation
}

\begin{abstract}
This article considers the main types of global environmental problems as crisis ecological situations that are relevant for the entire planet, the solution of which is possible only with the participation of all humanity. Global environmental problems closely related to other global world problems, they affect each other and the emergence of some leads to the emergence or aggravation of others. The paper is concerned that such a complex world problem as the demographic caused by the explosive growth of the world's population leads to a sharp increase in the burden on the environment due to an increase in people's needs for food, energy, housing, industrial goods, etc. Obviously, without solving the demographic problem, without stabilizing the population, it is impossible to restrain the development of crisis ecological processes on the planet. In turn, the ecological problems of desertification, deforestation, causing degradation and loss of agricultural land, lead to an aggravation of the world food problem. The ecological danger of such global problem as military is great. In this article, we have determined that environmental degradation leads to significant economic costs as a result of degradation of natural resources, pollution, deterioration of public health.
\end{abstract}

\section{Introduction}

In the 21 st century, the issue of the ecological problems became the most acute. The development of world technical progress, population growth, and irrational use of the Earth's resources led to an ecological catastrophe, which requires an immediate solution from the local level to the international one. The ecological situation concerns not only our country, Russia, but the whole Planet. It depends not on the life of single city, but of the whole of humanity as a whole. I decided to take this topic for my report, because I believe that people pay little attention to the environment, neglecting all the resources that it gives. The main problem of man is that he does not realize the scale and seriousness of this problem. And I, as a lawyer and just a person deeply interested in solving this problem, will try to convey to you the importance of the issue.

The term "ecology" originated in the framework of biology. Its author was professor of Jena University E. Haeckel in 1866 [1]. Ecology originally considered as part of biology, studying the interaction of living organisms, depending on the state of the environment. Later, the notion "ecosystem" appeared in the West, and in the USSR - "biocenosis" and

\footnotetext{
* Corresponding author: kovalenko1288@mail.ru
} 
"biogeocenosis", which introduced by academician V. N. Sukachev [2]. These terms are very similar. Originally, the term "ecology" meant a discipline that studies the evolution of fixed ecosystems. Even now, in the course of general ecology, the main place occupied by the problems of the biological plan in the main. In addition, this is incorrect, because the content of the subject is extremely narrow. While life itself significantly expands the range of problems solved by ecology.

At the end of the 20th century, humanity began to feel the approach of an ecological crisis. The ecological crisis of the late 20th century has a qualitatively different nature compared to all previous crises. This is the first crisis that has engulfed the entire planet and completely conditioned not by natural, but by technical and production reasons. The rate of change in the parameters of the biosphere turned out to be hundreds and thousands of times greater than the rate of its natural evolution.

The general, global degradation of the natural environment has begun. An important role in the development of the ecological crisis played by a complex social background, with the split of human society into competing blocs: West-East, developing countries-economically developed countries, and rural population-urban population.

The most important problems of humanity are the problem of ecology and the problem of war and peace. But which one is more important? Both represent a threat to the human population.

Economic and social inequality creates the desire to reach a higher level at any cost, national separatism leads to the ignoring of global environmental problems. Living in the village cannot perceive the severity of environmental problems of large cities. As elements of the pressure of civilization on the natural environment, there are high-cost technologies used in industry and agriculture, road transport and urbanization. The arms race plays an important role in the development of the ecological crisis. Almost uncontrolled by the public military industrial complexes of the developed countries of the world are the largest consumers of resources and energy.

A.V. Tabakova considered the main cause of the ecological crisis to be the type of organization of human society [3]. The ecological crisis is a crisis of philosophy, a crisis of spirituality. The degradation of the natural environment is not the result of simple, and not only technogenic, pressure on it, but a consequence of impoverishment of society's morality, blindness to the future consequences of the adopted lifestyle. Great contribution to the development of crisis phenomena adds the existing contradiction of personal and public interests, the prevalence of regional thinking over the global.

\section{Methods}

The current research uses the methods of observation, comparative legal studies, formal logic, description and interpretation. The goal of research is to show that the ecological problem have systemic nature and cannot be isolated from the issues of urban development, economics and personal intangible interests of population.

The research aims at analyzing some environmental problems of our time and draw attention to them [4-10]. A systematic literature review was performed for the construction of a theoretical-scientific reference on economic valuation applied to urban solid waste management. Searches were made to bases Portal de Periódicos (CAPES), Springer, Science Direct and SciELO. Articles available in the internet published from 2006 to 2015 were selected based on the following guiding question and descriptors.

The articles were selected after reading of both title and abstract and further identification of those related to the guiding question [11- 17]. 
The articles were investigated and Bardin's content analysis was adopted as theoretical fundamentals in the construction of the analysis categories (Bardin, 2011).

\section{Results}

Global environmental problems include:

1. Climate warming;

2. Reduction of biological diversity;

3. Degradation of the ozone layer;

4. Global air and water pollution.

Global warming. More attention is paid to the problem of global climate change, global warming. Its consequences can be manifested in the rise in sea level and in the flooding of many territories, in the reduction of production in the world of agricultural products, and in the exacerbation of the water deficit in the regions located to the north and south of the equator. All this can lead to disastrous consequences for hundreds of millions of people, especially in developing countries, many of which are located in the geographic areas of the most severe negative impact of global warming.

Causes of occurrence: emission of greenhouse gases into the atmosphere. Can lead to climate change on a global scale.

Measures to combat global warming:

- to reduce the level of carbon dioxide emissions;

- transition to carbon-free fuels;

- development of a more economical strategy for fuel use;

Ozone layer. Causes of the problem:

- emission of frion gases into the atmosphere;

- The destruction of the ozone layer leads to an increase in cancer.

The main ozone hole is above the Arctic. Depletion of the ozone layer in the atmosphere leads to an increase in the inflow to the Earth's surface of harmful ultraviolet solar radiation. Now the thickness of the ozone layer over areas with a temperate climate has decreased by about $10 \%$. Even a small amount of ultraviolet radiation is enough to harm people's health. Here the main disease is skin cancer, the spread of which in the world is rapidly increasing. Ultraviolet radiation is also one of the main causes of cataracts, which leads to a loss of vision of 17 million in year [18].

Complex problems due to depletion of the ozone layer can arise in agriculture, in food production, as more than two thirds of crops are damaged as a result of excessive ultraviolet radiation. This radiation is dangerous in the seas and oceans for plankton, which is an important element of the marine food chain.

Reduction of biological diversity. It is associated with the disappearance of many living organisms from the face of the earth due to intensive human activity. Due to its activities, a person either destroys organisms directly or destroys their habitats.

The average duration of species existence is 5-6 million years. For the last 200 million years about 900 thousand species have disappeared, or on average less than one species per year. At present, the rate of extinction of species is five orders of magnitude greater: 24 species disappear within 24 hours. The main causes of loss of biological diversity: loss of habitat. Excessive exploitation of biological resources, habitat pollution, the impact of introduced exotic species.

The ecological problem is a change in the natural environment, resulting in (anthropogenic impacts or natural disasters) leading to a disruption of the structure and functioning of nature. Global problems are caused by contradictions in social development, sharply increased scales of the impact of human activity on the world and are also associated with unevenness socio-economic and scientific and technological development of countries 
and regions. Solving global problems requires the deployment of international cooperation. Modern scientists believe that humanity already lives in a collapsing world in the face of an ever-growing cruel ecological crisis that is turning into a crisis of the whole civilization [19]. Ecological crisis, we can define as a violation of equilibrium in ecological systems and in the relationship of human society with nature. It is characterized, in particular, by the fact that a person, society and the state are unable to reverse the trend of deterioration of the state of the environment. The most important global environmental problems facing a modern man are:

- environmental pollution,

- the greenhouse effect,

- depletion of the "ozone layer",

- photochemical smog,

- acid rain,

- soil degradation,

- deforestation,

- desertification,

- waste problems,

- reduction of the gene pool of the biosphere, etc.

Pollution of the environment is the most urgent problem of our time, because anthropogenic activity affects all terrestrial seas: the atmosphere, hydrosphere and lithosphere. At the same time, the person, being the main culprit of the current ecological situation, is becoming its main victim: according to some data, about $40 \%$ of people die from pollution of water resources, air and soil cover in the world. If you want to help nature, start with yourself. Man - a brilliant creation of nature and an integral part of it, however, with the advent of new technologies and increasing population growth rates on the Earth, the planet suffers more and more people need to pay attention to energy saving. It is we who are people, we destroy non-renewable resources, destroy our flora and fauna, violate natural cycles, in one word - harm. Everything is changing around us: the animals begin to die out, and the islands go under water, entire cities destroyed by cataclysms, but only people continue to be boorish about the planet and with great enthusiasm to pump out those last grains that she needs so much. What is happening around us is the work of our own hands, and only after telling ourselves "STOP" we will have a chance to ask for forgiveness from the Earth.

We can offer such solutions as:

- to increase attention to the issues of nature protection and ensuring the rational use of natural resources;

- establish systematic control over the use of land, water, forests, mineral resources and other natural resources by enterprises and organizations;

- to increase attention to the issues of preventing pollution and salinization of soils, surface and groundwater;

- pay great attention to the preservation of the water protection and protective functions of forests, to the preservation and reproduction of flora and fauna, to the prevention of air pollution;

- strengthen the struggle against industrial and domestic noise.

Of course, many of these proposals have already applied in some areas of society, but this is likely to be only an exception than the rule that have been taken as the basis of activity. It is also worth noting which of the big list of problems should be addressed mainly, according to the World Wildlife Fund.

The first and most serious is the problem of global climate change. It is well known that Russia occupies a third place in the world (after the US and China) in terms of greenhouse gas emissions. Namely, greenhouse gases are the main cause of anthropogenic climate change. In addition, $60 \%$ of the territory of Russia is occupied by permafrost, which also suffers from greenhouse gases. Warming also leads to direct losses for the state, and this is 
no less than about 60 billion rubles. Because of climate change, agricultural land is suffering, a decline in yields is observed throughout the country, which cannot but worry in conditions of world hunger. In addition, it expected that warming will lead to the emergence of new diseases and dangerous microorganisms, especially in the southern regions of Russia. The second place in the importance of WWF has been the imperfection and inadequate elaboration of the environmental legislation of Russia [20]. Yes, various reforms implemented to improve the environmental situation. But they lack synchronism, there is no single effective strategy, which allows even the most unsafe projects to find loopholes in the law and to develop successfully. In addition, in Russia there is not enough, in comparison with European countries, alternative energy develops.

In third place - the Sochi Olympics-2014. WWF complains that although all legislative acts exist, all valuable natural areas are documented, in fact many norms are grossly violated. WWF draws the attention of the authorities to the fact that non-observance of these norms will negatively affect the reputation of Russia in the eyes of the rest of the world, and calls for toughening control over the construction of the Olympic village.

The fourth on the WWF list is the insufficient development of alternative energy. Experts of this organization believe that now is the most suitable time for the modernization of the economy and the enhanced development of energy-saving technologies. This will make Russia more attractive for foreign investors.

The fifth problem of Russian ecology lies in the human factor. Unfortunately, not every citizen is aware of his responsibility towards the nature of his own country. Talk about this relationship can be a long time, the topic is sick and many are familiar. But environmentalists are most perturbed by the consumer attitude towards the nature of those who should protect it, namely officials of different ranks. According to WWF, ecological consciousness needs to be developed, with the help of information technologies and necessarily on a personal example.

If you take into account Russia, according to statistics, Russians are concerned about the environmental situation and are aware of the environmental threat factors. But does the behavior of people change? By no means. For example, everyone continues to use cars, throws garbage in unauthorized places. This tendency will vanish in the future, since the car, for example, has status-prestige characteristics and there are many such situations. This is the complexity of solving the environmental problem, since responsibility assigned to each individual to change people's behavior. Such changes presuppose a change in valuenormative structures. The main vector of environmental policy should be set by the institution of state power. The primary task of the state is to increase the role of environmental education among the population. According to Art. 42 of the Constitution of the Russian Federation, every citizen has the right to reliable information on the state of the environment [21]. Unlike other branches of law, there is no environmental code in environmental law. The state establishes legal liability for the commission of environmental offenses: disciplinary, property, administrative, criminal. For example, the entire chapter 26 of the Criminal Code is devoted to environmental crimes, which identified 18 criminal offenses [22]. The legislation of the RF focuses on environmental education in our country. In the Federal Law "On Environmental Protection" of 10.01.2002, ecological culture is devoted to chapter 13 under the title "Basics of the formation of ecological culture" [23].

So, in order to solve the ecological problem of the world, it is first necessary to ensure environmental education from the preschool age, educate citizens about environmental problems through the media, flash mobs, actions, lectures, exhibitions. Show relevant programs not at night, but in the afternoon! What is also a global problem that I put in my work. The states of different countries should pay more attention to the ecological situation not only in their own country, but throughout the world. To become united and to act in the name of the common good-the preservation of life. 


\section{Conclusions}

In summary, an important measure on the way to solving modern environmental problems is the ecologization of production:

- development of non-waste technologies based on closed cycles;

- complex processing of raw materials;

- use of secondary resources;

- search for new sources of energy;

- wide introduction of biotechnologies;

- mandatory environmental impact assessment of new production projects;

- Development of environmentally sound forms of agricultural management with a permanent rejection of pesticides, etc.

An important direction in improving the current environmental situation is also reasonable self-limitation in the expenditure of natural resources, especially energy sources, which are of vital importance for human life.

Another measure of solving the environmental problem is the formation of environmental consciousness in the society. Ecological education and upbringing should be put on the state level, and with reference to high school education to become the most important element of the training of specialists of any profile.

\section{References}

1. B.V. Erofeev. Soviet Environmental Law. (Moscow, VYUZI, 2018)

2. R.Z. Livshits. Theory of Law: A Textbook. (Moscow, 2016)

3. A.V. Tabakova. Modern World and Environmental Education. Humanities and Education, 3 (2016)

4. T. Eshet, O.Ayalon \& M. Shechter. Resources, Conservation and Recycling, 46 (2016)

5. S. E. Shmelev \& J. R. Powel,. Ecological Economics, 59 (2016)

6. C. A.Armijo De Veg, S.Ojeda-Benítez, E. Ramírez-Barreto, A. Quintanilla-Montoya. Ingeniería Revista Académica de la FI-UADY, 10 (2016)

7. R. A. Begum, C. Siwar, J. J. Pereira, A. H. Jaafar. Waste Management, 27 (2017)

8. M. C. E. Lloréns, M. L. T. Torres, A. P. A. Arrechea, R. M. Navarro, A. F. Colomina. Revista CENIC Ciencias Biológicas, 38 (2017).

9. J. Cleary. Environment international, 35 (2018)

10. P. Sarkhel, S.Banerjee. Environment, Development and Sustainability, 12 (2017)

11. R. M. A.Albertin, E. Moraes, Neto G.Angelis, B. L. D. Angelis, E. Coverloni, F. F. S. Silva. Revista Agro@mbiente On-line, 4 (2017)

12. L. A.Nagashima, Junior C. Barros, C. C.Andrade, E. T. Silva, C. Hoshika. Acta Scientiarum. Technology, Maringá, 33 (2015)

13. V. Owusu, J. M. Boaherg, C. Sundberg. Journal of Environmental Studies and Sciences, $1(2015)$

14. H. Ali, N. Ali, A. R.Ahmad, M.Ibrahim, S.Ahmad, S. Yaacob. Advances in natural and applied sciences, 6 (2017)

15. A.Durán Moreno, G. M.arcés Rodríguez, A. R. Velasco, Marín J. C. Enriquez, R. Gutiérrez Lara. Rev. Int. Contam. Ambient, México, 29 (2015)

16. URL: www.revistas.unijui.edu.br/index.php/desenvolvimentoemquestao/article/view/2903

17. V. F. Nascimento, A. C. Sobral, P. R. Andrade. Evolução e desafios no gerenciamento dos resíduos sólidos urbanos no Brasil. Rev. Ambient. Água, Taubaté, 10 (2018)

18. K.E. Kovalenko. World Applied Sciences Journal, 7 (2015) 
19. B.I. Kochurov. Geography of ecological situations (eco-diagnostics of territories). (Moscow, IG RAS, 2014)

20. URL: http://www.wwf.ru/ (07.07.2018)

21. URL: http://www.consultant.ru/document/cons_doc_LAW_28399/ (07.07.2018)

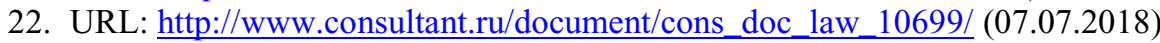

23. URL: http://www.consultant.ru/document/cons_doc_LAW_34823/(07.07.2018 